\title{
Making decisions to conserve species under climate change
}

\author{
Luke P. Shoo • Ary A. Hoffmann • Stephen Garnett • \\ Robert L. Pressey • Yvette M. Williams • Martin Taylor • \\ Lorena Falconi • Colin J. Yates • John K. Scott • \\ Diogo Alagador • Stephen E. Williams
}

Received: 4 December 2011 / Accepted: 16 January 2013 / Published online: 2 February 2013

C The Author(s) 2013. This article is published with open access at Springerlink.com

\begin{abstract}
Severe impacts on biodiversity are predicted to arise from climate change. These impacts may not be adequately addressed by conventional approaches to conservation. As a result, additional management actions are now being considered. However, there is currently limited guidance to help decision makers choose which set of actions (and in what order) is most appropriate for species that are considered to be vulnerable. Here, we provide a decision framework for the full complement of actions aimed at conserving species under climate change from ongoing conservation in existing refugia through various forms of mobility enhancement to ex situ conservation outside the natural environment. We explicitly recognize that allocation of conservation resources toward particular actions may be governed by factors such as the likelihood of success, cost and likely co-benefits to non-target species in addition to perceived vulnerability of individual species. As such, we use expert judgment of probable tradeoffs in resource allocation to inform the sequential evaluation of proposed management interventions.
\end{abstract}

L. P. Shoo • Y. M. Williams $•$ L. Falconi $\cdot$ S. E. Williams

Centre for Tropical Biodiversity and Climate Change, School of Marine and Tropical Biology, James

Cook University of North Queensland, Townsville, QLD 4811, Australia

\section{A. A. Hoffmann}

Centre for Environmental Stress and Adaptation Research, Bio21 Institute and Department of Zoology, The University of Melbourne, Melbourne, VIC 3010, Australia

S. Garnett

Research Institute for the Environment and Livelihoods, Charles Darwin University, Darwin, NT 0909, Australia

R. L. Pressey

Australian Research Council Centre of Excellence for Coral Reef Studies, James Cook University, Townsville, QLD 4811, Australia

M. Taylor

WWF- Australia, 1/17 Burnett Lane, Brisbane, QLD 4000, Australia

C. J. Yates

Science Division, Western Australian Department of Environment and Conservation, LMB 104, Bentley Delivery Centre, Perth, WA 6983, Australia 
Anthropogenic emissions of greenhouse gases have committed Earth to warmer global temperatures and associated changes in the climate system through the 21 st century (Meehl et al. 2007). Some loss of global biodiversity is predicted as a consequence (Thomas et al. 2004), regardless of policy intervention to reduce emissions. Existing conservation strategies will remain relevant (Hunter et al. 2010), but additional management actions are being considered to ameliorate climate change impacts that cannot be offset by conventional approaches to conservation that generally focus on existing locations (Heller and Zavaleta 2009). Importantly, however, managers lack a clear framework that explicitly sets out the potential actions for a particular species, the relative costs and likelihood of success of different actions, potential co-benefits for non-target species as well as important knowledge gaps that (if resolved) might improve adaptation. Here, we provide a decision framework in which conservation actions are linked to evaluations of species' genetic adaptability and potential to adjust their ranges in response to climate change. We believe that this is an important first step toward optimizing allocation of resources aimed at conserving species under climate change.

The first challenge is to ensure that vulnerable species are identified as candidates for management intervention (Williams et al. 2008). High-risk species might be characterized by a high probability that the area of environmental suitability will decline by a threshold amount within a specified timeframe (e.g. $30 \%$ within 3 generations, IUCN Red List Vulnerable criteria) as a direct consequence of climate change in conjunction with actual observations of declines and/or additional empirical evaluations of vulnerability (Thomas et al. 2011).

Next we seek to match likely species response scenarios with interventions that might assist these adjustments, beginning with low level interventions and progressively deferring to higher levels of intervention (lower in Fig. 1). The logical motivation for this sequencing is the presumption that higher levels of intervention are also likely to be more expensive, less certain, have fewer co-benefits to non-target species and be where societal values will increasing impinge on which species will be saved or lost. Although there are likely to be uncertainties and anomalies with specific species, we believe that this structured approach to evaluating the necessity and appropriateness of different adaptation action/s, informed by the expected cost of management actions, the likelihood that the management will succeed (e.g. Joseph et al. 2009) and also opportunities for joint benefits arising from actions (e.g. restoration of habitat within shared refugia), represents an important advance on generic recommendations (e.g. Heller and Zavaleta 2009). The approach also builds on previous efforts that have focused mainly on vulnerability (Dawson et al. 2011) or evaluations of resistance and resilience to prioritize actions (Prober et al. 2012).

\author{
J. K. Scott \\ CSIRO Climate Adaptation Flagship, Private Bag 5, PO Wembley, WA 6913, Australia
}

D. Alagador

"Rui Nabeiro" Biodiversity Chair, CIBIO, University of Évora, Casa Cordovil $2^{\circ}$ andar, Rua Dr. Joaquim Henrique da Fonseca, 7000-890 Évora, Portugal

Present Address:

L. P. Shoo $(\bowtie)$

School of Biological Sciences, The University of Queensland, St Lucia, QLD 4072, Australia

e-mail: 1.shoo@uq.edu.au 


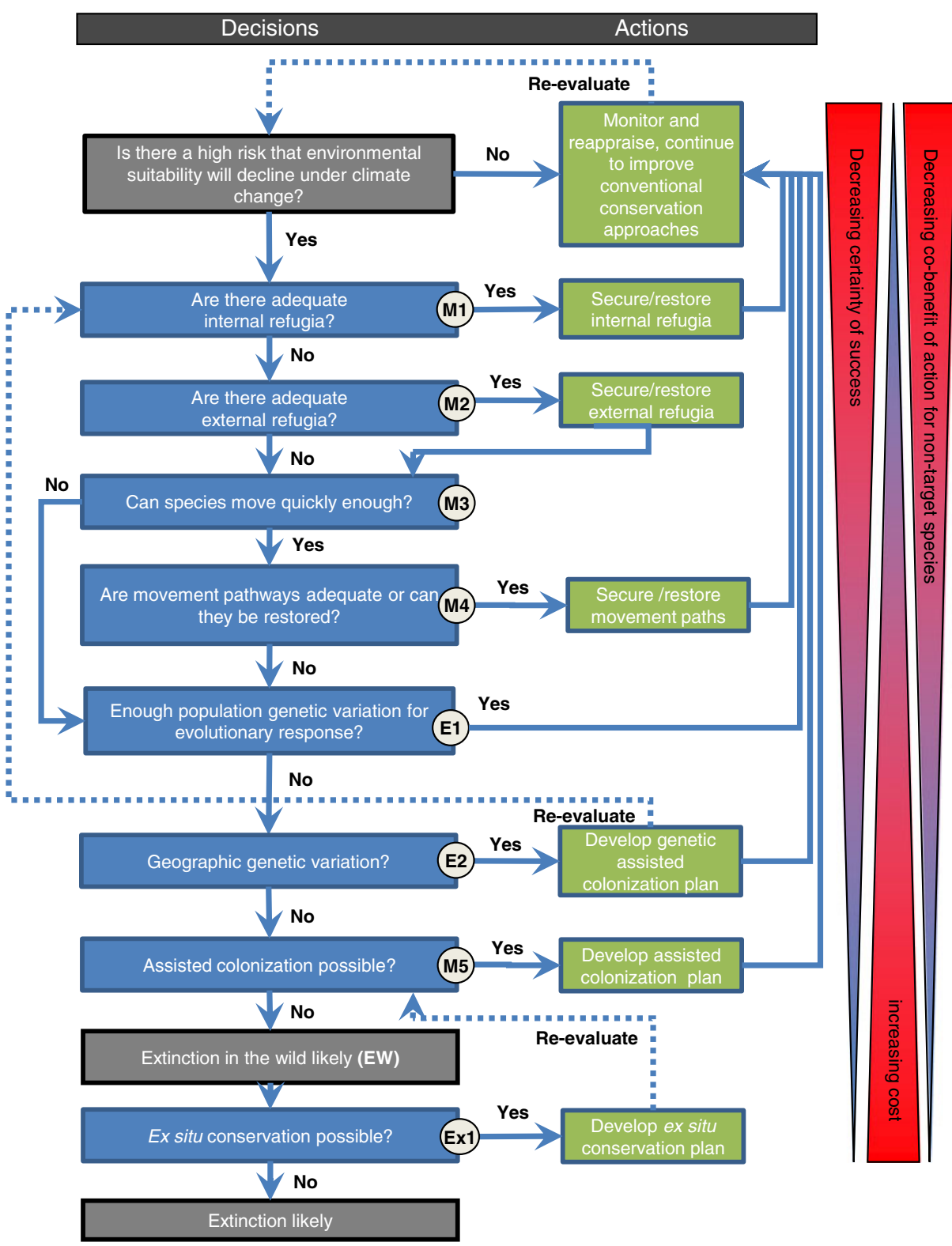

Fig. 1 Decision framework for management actions focused on ameliorating impacts of climate change on wild species. ' $M$ ' is used to identify movement options for species, while ' $E$ ' and ' $E x$ ' concern evolutionary and ex situ options respectively

Actions concerned with species' spatial adjustments begin with assessments of potential refugia. The term "refugia" was originally used to describe locations where species survived the last glacial period (Bennett and Proven 2008). Increasingly, it refers to areas buffered from the impacts of contemporary climate change (Ashcroft 2010; Keppel et al. 2011). The protection of these areas has emerged as a priority for biodiversity management in the face of 
climate change (Heller and Zavaleta 2009). Analytical tools are already being used to identify important refugia, for example, drought refugia in Australia (Mackey et al. 2012), cool environments in Australian tropical rainforests (Shoo et al. 2011), and geomorphological features that promote stable, wet environments in the Neotropics (Killeen et al. 2007). These tools could be rapidly expanded and generated at increasingly fine scales (e.g. Ashcroft et al. 2012) to target conservation investment (e.g. land protection and restoration) toward existing locations where species are most likely to persist under climate change (Shoo 2010).

More difficult will be evaluating the adequacy of refugia to promote the persistence of species given large uncertainties around predictions of both climate and species responses (Fig. 1- M1). Thresholds could be set for area of suitable climate and extent to which refugial climate stays within predetermined tolerances. Alternatively, it may be sensible to nominate a threshold population size above which persistence to the end of the century is highly likely, though caution is needed to avoid 'magic numbers'. Rather, thresholds based on empirical species-specific data should be used wherever possible (Flather et al. 2011; Garnett and Zander 2011). Failure to meet these criteria could then be used as a trigger to prompt more interventionist management actions.

Internal refugia are those within the present ranges of species, providing the most certain strongholds and requiring least intervention. In some cases, however, there will be little or no spatial overlap between suitable environments predicted under current and future climates. This requires a search for external refugia - climatically suitable areas outside species' present ranges (Fig. 1 - M2) - or tracking of suitable habitat. For example, Willis et al. (2009) used species distribution models to identify climatically suitable but unoccupied areas of the UK to facilitate northward range shifts of two butterfly species.

The next decision is whether those species that need to move will be able to do so quickly enough to track suitable climates (Fig. 1 - M3). Local velocity of temperature change along the Earth's surface has a global mean of $0.42 \mathrm{kmyr}^{-1}$ but is predicted to be lower in mountain biomes and higher in flat areas like flooded grasslands, mangroves and deserts (Loarie et al. 2009). Dispersal permitting, movement pathways that will allow species to move to external refugia need to be identified and conserved (Fig. 1 - M4). Phillips et al. (2008) showed how land protection could be optimized to facilitate shifts in the geographic ranges of South African plants under climate change. The value of such intervention is supported by emerging evidence that protected areas facilitate species' range expansions (Thomas et al. 2012). However, on its own, protection of remaining habitat within movement pathways may not be enough. There is already evidence that some species are not shifting their ranges at a pace comparable to rates of climate change (Chen et al. 2011) and habitat specialists and species with an inability to occupy human-dominated landscapes appear to be particularly slow to move (Warren et al. 2001). Managers might therefore need to couple information on available movement pathways with actions designed to restore habitat within range shift corridors. As with population size, it will be important to reappraise management decisions, especially given that the 'push and pull of climate change' may result in unexpected patterns of range shift (e.g. Tingley et al. 2012).

Natural colonization of external refugia might not be achievable for species restricted to highly fragmented habitats or that have range-shift routes blocked by physical barriers (e.g. major rivers, urban centers, land use change) (Asner et al. 2010; Yates et al. 2010). Distances required to reach external refugia or track habitats are expected to be large in some circumstances (Midgley et al. 2003; Wright et al. 2009; Yates et al. 2010). In select cases, where there is good reason to believe that a species has the evolutionary capacity to adapt to climate change, it may be preferable to monitor and reappraise rather than pursue intervention (Fig. 1 - E1). Otherwise, the controversial actions of genetic translocation (Fig. 1 - E2) or assisted 
colonization (Fig. 1 - M5) might be considered to prevent extinction in the wild (Miller et al. 2012). There is now evidence that evolutionary adaptation has occurred in a variety of species in response to climate change over relatively short time spans (e.g., 5 to 30 years) (Bradshaw and Holzapfel 2006). Ability to adapt is likely to be a function of heritable variation in selected traits, indirect effects of population size on evolution, and the rate of environmental change (Berger and Lynch 1995; Hoffmann and Sgrò 2011). Further work is needed to examine the genetic architecture of traits that may be linked to species distributions (Kellermann et al. 2009). Such information will be critical in determining whether enough population genetic variation exists to support an evolutionary response, though there remains great uncertainty about the link between such variation and adaptive capacity. In assessing vulnerability to climate change there must also be recognition that some species have persisted in situ through multiple climates with little or no genetic variation (Byrne 2008).

Genetic assisted colonizations aimed at increasing population fitness and the evolutionary potential of populations could involve introducing genetic material from one population into another. One form of genetic assisted colonization involves genetic rescue whereby genetic material is introduced to rescue an existing population from loss of fitness due to inbreeding depression or the accumulation of deleterious alleles (Hedrick and Fredrickson 2010), unless there is evidence that deleterious genes have already been purged from such populations (Mosblech et al. 2011). In general, however, locally adapted alleles in resident populations can be maintained (i.e., not swamped by outside gene flow) by ensuring that around $20 \%$ of the population carries genes from the introduced area (Hedrick and Fredrickson 2010). An example of this approach is the rescue of the Florida panther by introducing genetic material from Texas (Johnson et al. 2010). This type of genetic assisted colonization is not usually considered within the framework of evolutionary climatic adaptation. Alternatively, genetic material may be introduced to boost genetic variation in populations and restore evolutionary potential (Weeks et al. 2011). This approach requires that populations then expand rapidly to prevent further loss of genetic variation (Willi et al. 2006) unless there are repeated introductions of new genetic material (Weeks et al. 2011).

Another form of genetic assisted colonization involves the introduction of genotypes into populations that are adapted to different conditions. This approach has been promoted particularly within the context of revegetation and restoration. Conventionally, restoration has involved local provenancing where material for propagating plants is selected from near a target area. However, it has now been recognized that provenancing might instead involve a mix of locally adapted genotypes and those more suited to future conditions (Broadhurst et al. 2008; Jones and Monaco 2009; Sgrò et al. 2010). This approach is particularly applicable to long-lived species where in situ adaptation might be too slow to keep pace with rapid environmental change (Lynch and Lande 1993). There is a risk that new genetic material can produce a loss of population fitness through outbreeding depression, although this risk appears to have been overstated and it can be minimized by following some simple guidelines (Frankham et al. 2011; Weeks et al. 2011). Successful augmentation of evolutionary potential could then be followed by a reappraisal of movement options beginning with evaluation of the adequacy of internal refugia.

At the species level, decision frameworks are already available for assessing possible candidates for assisted colonization and optimal timing of intervention (Hoegh-Guldberg et al. 2008; McDonald-Madden et al. 2011). Experimental introductions of two UK butterflies demonstrate the feasibility of applying assisted colonization in this context (Willis et al. 2009) However, as an adaptation strategy, assisted colonization remains a controversial action (Ricciardi and Simberloff 2009) as there is concern that risks may ultimately outweigh the benefits (Webber et al. 2011). 
It is important to recognize that intervention to assist evolutionary adaptation or movement will not be able to forestall the loss of all species in the wild. If a species is confined to a disappearing climate and cannot mount an evolutionary response, then extinction in the wild is likely. Ex situ conservation such as zoos, botanical gardens, seed banks and tissue storage might then be invoked to prevent extinction (Fig. 1-Ex1), as is already happening with a range of species now listed as Extinct in the Wild. However, the more intensive the intervention the higher the likely costs. This will likely increase pressure on managers to make some hard decisions - a situation that could be made worse depending on how much society limits the amount of funding available to respond to these emerging challenges (Bottrill et al. 2008). In any case, for species that are successfully maintained in captivity, it would be desirable to periodically reevaluate opportunities for repatriation back into the wild.

In conclusion, transparent decision making linked to specific management interventions will be critical in assisting biological systems to respond to climate change. We have provided a hierarchical framework with actions arranged according to the expected level of intervention and potential cost, probability of success and likely co-benefits. We have used our best judgment to inform this process but acknowledge that new information may in turn cause us to reflect on the preferred sequencing of potential intervention strategies presented in this framework. Research now has an important role to play in decreasing uncertainty, refining information on costs, benefits and risks of alternative actions, and optimizing resource allocation among projects (Joseph et al. 2009). It has yet to be determined, for example, whether restoration of movement corridors will be more beneficial and less expensive than expanding the area of existing conservation reserves (Doerr et al. 2011; Hodgson et al. 2009) or assisted colonization. Further, advances in spatial modeling (e.g. fine sale climate surfaces) and quantification of adaptive variation (functional genomics) are progressing at a rapid pace meaning that the information needed to use the framework is becoming increasingly available. Similarly, advances in decision science are providing avenues to tackle the problem of resource allocation in situations where information is uncertain or incomplete.

Acknowledgments This paper is a product of a National Climate Change Adaptation Research Facility sponsored "Dynamic Conservation Planning" workshop. This research was supported by a Marine and Tropical Sciences Research Facility funded Fellowship to L.P. Shoo and funding from the Australian Government's National Environmental Research Program. We thank three anonymous reviewers for their valuable comments.

Competing financial interest The authors declare no conflict of interest.

Open Access This article is distributed under the terms of the Creative Commons Attribution License which permits any use, distribution, and reproduction in any medium, provided the original author(s) and the source are credited.

\section{References}

Ashcroft MB (2010) Identifying refugia from climate change. J Biogeogr 37:1407-1413

Ashcroft MB, Gollan JR, Warton DI, Ramp D (2012) A novel approach to quantify and locate potential microrefugia using topoclimate, climate stability, and isolation from the matrix. Glob Chang Biol 18:1866-1879

Asner GP, Loarie SR, Heyder U (2010) Combined effects of climate and land-use change on the future of humid tropical forest. Conserv Lett 3:395-403

Bennett KD, Proven J (2008) What do we mean by 'refugia'. Quaternary Sci Rev 27:2449-2455

Berger R, Lynch M (1995) Evolution and extinction in a changing environment - a quantitative-genetic analysis. Evolution 49:151-163 
Bottrill M, Joseph LM, Carwardine J, Bode M, Cook C, Game ET, Grantham H, Kark S, Linke S, McDonaldMadden E, Pressey RL, Walker S, Wilson KA, Possingham H (2008) Is conservation triage just smart decision-making? Trends Ecol Evol 23:649-654

Bradshaw WE, Holzapfel CM (2006) Evolutionary response to rapid climate change. Science 312:1477-1478

Broadhurst LM, Lowe A, Coates DJ, Cunningham SA, McDonald M, Vesk PA, Yates C (2008) Seed supply for broadscale restoration: maximizing evolutionary potential. Evol Appl 1:587-597

Byrne M (2008) Evidence for multiple refugia at different time scales during Pleistocene climatic oscillations in southern Australia inferred from phylogeography. Quaternary Sci Rev 27:2576-2585

Chen I-C, Hill JK, Ohlemüller R, Roy DB, Thomas CD (2011) Rapid range shifts of species associated with high levels of climate warming. Science 333:1024-1026

Dawson TP, Jackson ST, House JI, Prentice IC, Mace GM (2011) Beyond predictions: biodiversity conservation in a changing climate. Science $332: 53-58$

Doerr VAJ, Barrett T, Doerr ED (2011) Connectivity, dispersal behaviour and conservation under climate change: a response to Hodgson et al. J Appl Ecol 48:143-147

Flather CH, Hayward GD, Beissinger SR, Stephens PA (2011) A general target for MVPs: unsupported and unnecessary. Trends Ecol Evol 26:620-622

Frankham R, Ballou JD, Eldridge MDB, Lacy RC, Ralls K, Dudash MR, Fenster CB (2011) Predicting the probability of outbreeding depression. Conserv Biol 25:465-475

Garnett ST, Zander KK (2011) Minimum viable population size ignores evolutionary history. Trends Ecol Evol 26:618-619

Hedrick P, Fredrickson R (2010) Genetic rescue guidelines with examples from Mexican wolves and Florida panthers. Conservat Genet 11:615-626

Heller NE, Zavaleta ES (2009) Biodiversity management in the face of climate change: a review of 22 years of recommendations. Biol Conserv 142:14-32

Hodgson JA, Thomas CD, Wintle BA, Moilanen A (2009) Climate change, connectivity and conservation decision making: back to basics. J Appl Ecol 46:964-969

Hoegh-Guldberg O, Hughes L, McIntyre S, Lindenmayer DB, Parmesan C, Possingham HP, Thomas CD (2008) Assisted colonization and rapid climate change. Science 321:345-346

Hoffmann AA, Sgrò CM (2011) Climate change and evolutionary adaptation. Nature 470:479-485

Hunter M Jr, Dinerstein E, Hoekstra J, Lindenmayer D (2010) A call to action for conserving biological diversity in the face of climate change. Conserv Biol 24:1169-1171

Johnson WE, Onorato DP, Roelke ME, Land ED, Cunningham M, Belden RC, McBride R, Jansen D, Lotz M, Shindle D, Howard J, Wildt DE, Penfold LM, Hostetler JA, Oli MK, O'Brien SJ (2010) Genetic restoration of the Florida panther. Science 329:1641-1645

Jones TA, Monaco TA (2009) A role for assisted evolution in designing native plant materials for domesticated landscapes. Front Ecol Environ 7:541-547

Joseph LN, Maloney RF, Possingham HP (2009) Optimal allocation of resources among threatened species: a project prioritization protocol. Conserv Biol 23:328-338

Kellermann V, van Heerwaarden B, Sgro CM, Hoffmann AA (2009) Fundamental evolutionary limits in ecological traits drive Drosophila species distributions. Science 325:1244-1246

Keppel G, Van Niel KP, Wardell-Johnson GW, Yates CJ, Byrne M, Mucina L, Schut AGT, Hopper SD, Franklin SE (2011) Refugia: identifying and understanding safe havens for biodiversity under climate change. Glob Ecol Biogeogr 21:393-404

Killeen TJ, Douglas M, Consiglio T, Jørgensen PM, Mejia J (2007) Dry spots and wet spots in the Andean hotspot. J Biogeogr 34:1357-1373

Loarie SR, Duffy PB, Hamilton H, Asner GP, Field CB, Ackerly DD (2009) The velocity of climate change. Nature 462:1052-1055

Lynch M, Lande R (1993) Evolution and extinction in response to environmental change. In: Kareiva PM, Kingsolver JG, Huey RB (eds) Biotic interactions and global change. Sinauer, Sunderland, pp 234-250

Mackey BG, Berry S, Hugh S, Ferrier S, Harwood T, Williams K (2012) Ecosystem greenspots: identifying potential drought, fire and climate-change micro-refuges. Ecol Appl 22:1852-1864

McDonald-Madden E, Runge MC, Possingham HP, Martin TG (2011) Optimal timing for managed relocation of species faced with climate change. Nat Clim Change 1:261-265

Meehl GA, Stocker TF, Collins WD, Friedlingstein P, Gaye AT, Gregory JM, Kitoh A, Knutti R, Murphy JM, Noda A, Raper SCB, Watterson IG, Weaver AJ, Zhao Z-C (2007) Global climate projections. In: Solomon S, Qin D, Manning M, Chen Z, Marquis M, Averyt KB, Tignor M, Miller HL (eds) Climate change 2007: the physical science basis. Cambridge University Press, Cambridge, pp 747-845

Midgley GF, Hannah L, Millar D, Thuiller W, Booth A (2003) Developing regional and species-level assessments of climate change impacts on biodiversity in the Cape Floristic Region. Biol Conserv 112:87-97 
Miller KA, Miller HC, Moore JA, Mitchell NJ, Cree A, Allendorf FW, Sarre SD, Keall SN, Nelson NJ (2012) Securing the demographic and genetic future of Tuatara through assisted colonization. Conserv Biol 26:790-798

Mosblech NAS, Bush MB, van Woesik R (2011) On metapopulations and microrefugia: palaeoecological insights. J Biogeogr 38:419-429

Phillips SJ, Williams P, Midgley G, Archer A (2008) Optimizing dispersal corridors for the Cape Proteaceae using network flow. Ecol Appl 18:1200-1211

Prober SM, Thiele KR, Rundel PW, Yates CJ, Berry SL, Byrne M, Christidis L, Gosper CR, Grierson PF, Lemson K, Lyons T, Macfarlane C, O'Connor MH, Scott JK, Standish RJ, Stock WD, van Etten EJB, WardellJohnson GW, Watson A (2012) Facilitating adaptation of biodiversity to climate change: a conceptual framework applied to the world's largest Mediterranean-climate woodland. Clim Chang 110:227-248

Ricciardi A, Simberloff D (2009) Assisted colonization is not a viable conservation strategy. Trends Ecol Evol 24:248-253

Sgrò CM, Lowe AJ, Hoffmann AA (2010) Building evolutionary resilience for conserving biodiversity under climate change. Evol Appl 4:326-337

Shoo LP (2010) Planning for biodiversity in future climates. Science 327:1452

Shoo LP, Storlie C, VanDerWal J, Little J, Williams SE (2011) Targeted protection and restoration to conserve tropical biodiversity in a warming world. Glob Chang Biol 17:186-193

Tingley MW, Koo MS, Moritz C, Rush AC, Beissinger SR (2012) The push and pull of climate change causes heterogeneous shifts in avian elevational ranges. Global Change Biol

Thomas CD, Cameron A, Green RE, Bakkenes M, Beaumont LJ, Collingham YC, Erasmus BFN, de Siqueira MF, Grainger A, Hannah L, Hughes L, Huntley B, van Jaarsveld AS, Midgley GF, Miles L, OrtegaHuerta MA, Townsend Peterson A, Phillips OL, Williams SE (2004) Extinction risk from climate change. Nature 427:145-148

Thomas CD, Hill JK, Anderson BJ, Bailey S, Beale CM, Bradbury RB, Bulman CR, Crick HQP, Eigenbrod F, Griffiths HM, Kunin WE, Oliver TH, Walmsley CA, Watts K, Worsfold NT, Yardley T (2011) A framework for assessing threats and benefits to species responding to climate change. Methods Ecol Evol 2:125-142

Thomas CD, Gillingham PK, Bradbury RB, Roy DB, Anderson BJ, Baxter JM, Bourn NAD, Crick HQP, Findon RA, Fox R, Hodgson JA, Holt AR, Morecroft MD, O’Hanlon NJ, Oliver TH, Pearce-Higgins JW, Procter DA, Thomas JA, Walker KJ, Walmsley CA, Wilson RJ, Hill JK (2012) Protected areas facilitate species' range expansions. Proc Natl Acad Sci USA

Warren MS, Hill JK, Thomas JA, Asher J, Fox R, Huntley B, Roy DB, Telfer MG, Jeffcoate S, Harding P, Jeffcoate G, Willis SG, Greatorex-Davies JN, Moss D, Thomas CD (2001) Rapid responses of British butterflies to opposing forces of climate and habitat change. Nature 414:65-69

Webber BL, Scott JK, Didham RK (2011) Translocation or bust! A new acclimatization agenda for the 21st century? Trends Ecol Evol 26:495-496

Weeks AR, Sgrò CM, Young AG, Frankham R, Mitchell NJ, Miller KA, Byrne M, Coates DJ, Eldridge MDB, Sunnucks P, Breed MF, James EA, Hoffmann AA (2011) Assessing the benefits and risks of translocations in changing environments: a genetic perspective. Evol Appl 4:709-725

Willi Y, Van Buskirk J, Hoffmann AA (2006) Limits to the adaptive potential of small populations. Annu Rev Ecol Evol Syst 37:433-458

Williams SE, Shoo LP, Isaac JL, Hoffmann AA, Langham G (2008) Towards an integrated framework for assessing the vulnerability of species to climate change. PLoS Biol 6:e325

Willis SG, Hill JK, Thomas CD, Roy DB, Fox R, Blakeley DS, Huntley B (2009) Assisted colonization in a changing climate: a test-study using two U.K. butterflies. Conserv Lett 2:46-52

Wright SJ, Muller-Landau HC, Schipper J (2009) The future of tropical species on a warmer planet. Conserv Biol 23:1418-1426

Yates CJ, McNeill A, Elith J, Midgley GF (2010) Assessing the impacts of climate change and land transformation on Banksia in the South West Australian Floristic Region. Divers Distrib 16:187-201 